\title{
PELATIHAN PEMBELAJARAN DARING YANG INTERAKTIF DAN MENYENANGKAN DI PERGURUAN ISLAM MIFTAHUL HUSNA
}

\author{
Jane Elnovreny ${ }^{1}$, Rizki Maulida ${ }^{2}$, Jernih Donda Sinurat ${ }^{3}$ \\ ${ }^{1,2}$ Program Studi Sistem Informasi, Fakultas Teknik dan Ilmu Komputer \\ ${ }^{3}$ Program Studi Teknik Informatika, Fakultas Teknik dan Ilmu Komputer \\ Universitas Potensi Utama \\ Email: elnovreny311jane@gmail.com ${ }^{1)}$
}

\begin{abstract}
The pandemic of COVID-19 that has engulfed the whole world lately has become an unusual challenge. It grow the new habits to social distancing, including to working and studying from home. The teaching and learning process is carried out from home by all the teachers and students without exception. Learning from home is known as online. One of the schools in Medan that uses an online system is Perguruan Islam Miftahul Husna. At this school, there were many complaints from teachers and students when doing online learning which was considered boring because of reduced interaction between teacher and student. Learning media is needed to make learning process interactive and interesting. The media that was chosen must be media that keep students interested in learning and can be easily done by teachers. Kahoot application was chosen because can be used in any subject, provides benefits to students where they can be helped in recalling the material, making them more excited, not feeling bored and being able to participate actively in doing the exercises. This game raises competition and challenged them to be the best in class. With this increased interest and motivation, teachers can make Kahoot an alternative for online learning
\end{abstract}

Keywords: COVID-19, Online learning, Learning Media

\begin{abstract}
Abstrak. Pandemi COVID-19 yang terjadi melanda seluruh dunia menjadi tantangan yang tidak biasa. Keadaan ini menumbuhkan kebiasaan baru untuk sosial distancing termasuk membiasakan diri untuk bekerja dan belajar dari rumah. Proses belajar mengajar dilakukan dari rumah baik oleh guru dan siswa tanpa terkecuali. Pembelajaran dari rumah ini dikenal dengan istilah daring. Salah satu sekolah dikota Medan yang menggunakan sistem daring adalah Perguruan Islam Miftahul Husna. Di sekolah tersebut banyak didapati keluhan dari guru maupun siswa saat melakukan pembelajaran daring yang dianggap membosankan karena berkurangnya interaksi antara guru dan murid. Media pembelajaran sangat dibutuhkan untuk membuat proses pembelajaran menjadi interaktif dan menyenangkan. Media yang dipilih dalam pembelajaran daring haruslah media yang membuat para siswa tertarik belajar dan juga yang dapat dengan mudah dilakukan oleh para guru tentunya. Media Kahoot dipilih karena dapat digunakan dalam mata pelajaran apapun dan memberikan manfaat kepada siswa dimana dapat membantu dalam mengingat kembali materi belajar, membuat mereka lebih bersemangat, merasa senang, tidak merasa bosan dan dapat berpartisipasi dengan aktif dalam mengerjakan latihan-latihan. Game ini memunculkan kompetisi diantara para siswa sehingga mereka tertantang untuk menjadi yang terbaik di kelas. Dengan peningkatan minat dan motivasi ini, maka guru-guru dapat menjadikan Kahoot menjadi salah satu alternatif pembelajaran saat daring.
\end{abstract}

Kata kunci : COVID-19, Daring, Media Pembelajaran

\section{PENDAHULUAN}

Pandemi COVID-19 yang terjadi melanda seluruh dunia akhir-akhir ini menjadi salah satu kekhawatiran seluruh lapisan masyarakat termasuk masyarakat Indonesia khususnya warga Medan. Pandemi ini menjadi tantangan yang tidak biasa dan belum pernah terjadi sebelumnya karena mengubah kebiasaan dan seluruh kegiatan para warga. Warga tidak lagi mendapat kebebasan untuk dapat beraktivitas seperti biasanya namun disisi lain membuat warga menumbuhkan kebiasaan baru untuk membiasakan diri untuk sosial distancing termasuk membiasakan diri untuk bekerja dari rumah.

Kebiasaan baru untuk bekerja dari rumah ini juga dirasakan di bidang pendidikan. Proses belajar mengajar dilakukan dari rumah baik oleh guru dan siswa tanpa terkecuali. Pembelajaran dari rumah ini dikenal dengan istilah daring. Menurut Ahmad Rusdiana dkk dalam Marbun (2020) menggambarkan bahwa pandemi covid-19 
ini merubah kebiasaan para guru atau pun dosen dalam melakukan pembelajaran konvensional menjadi harus terbiasa dengan pembelajaran sistem daring. Salah satu sekolah dikota medan yang menggunakan sistem daring adalah Perguruan Islam Miftahul Husna. Di sekolah tersebut banyak didapati keluhan yang berasal dari guru maupun siswa saat melakukan pembelajaran daring.

Pada kenyataannya pembelajaran daring ini tidak semudah teori semata. Beberapa masalah yang ditemukan oleh guru dan murid adalah pembelajaran daring dianggap membosankan. Para siswa hanya dituntut untuk mengerjakan secara manual lalu difoto dan dikumpulkan kepada guru lewat media whatsapp atau pun email. Kegiatan ini terkadang mengurangi interaksi antara guru dan murid. Pembatasan pertemuan antara guru dan siswa mengharuskan tenaga pengajar kreatif dan inovatif dalam mendesain pola pembelajaran. Oleh sebab itu, para guru perlu mengembangkan skillnya untuk dapat mengajar secara kreatif dan inovatif. Untuk itu guru-guru perlu mengikuti pelatihan pembuatan media pembelajaran. Pelatihan merupakan jenis program pembelajaran yang menitikberatkan pada peningkatan keterampilan individu dalam melaksanakan tugasnya (Simbolon, 2020)

Media pembelajaran sangat dibutuhkan untuk membuat proses pembelajaran bisa menjadi interaktif dan menyenangkan. Media yang dipilih khususnya dalam pembelajaran daring ini haruslah media yang tepat membuat para siswa tertarik untuk belajar dan juga yang dapat dengan mudah dilakukan oleh para guru. Dengan demikian media pembelajaran yang sangat mudah dipilih adalah dengan smartphone yang bisa dipakai dimana saja, kapan saja dan oleh siapa saja. Media pembejaran jenis ini juga sering disebut dengan media pembelajaran online. Menurut Putranti (2013) media pembelajaran online adalah salah satu bentuk media pembelajaran jarak jauh dengan menggunakan fasilitas internet sehingga mereka dapat saling berkomunikasi secara online. Media pembelajaran online dapat dipahami sebagai suatu proses pembelajaran yang memanfaatkan teknologi informasi berupa komputer yang dilengkapi dengan sarana telekomunikai (internet, intranet, ekstranet) dan multimedia (grafis, audio, video) sebagai media utama dalam penyampaian materi dan interaksi antara pengajar dan pembelajar (Putranti, 2013).

Berfokus pada masalah ini maka kami tertarik untuk mengadakan penyuluhan atau pelatihan dimana pelatihan ini bertujuan untuk melakukan bimbingan kepada para guru untuk dapat mengembangkan pembelajaran daring yang interaktif dan menyenangkan bagi para siswa dan mengetahui manfaat pengembangan pembelajaran daring yang interaktif.

\section{METODE PELAKSANAAN}

Program pengabdian masyarakat ini dilakukan di area Perguruan Islam Miftahul Husna. Metode yang dilakukan adalah dengan memberikan pendidikan untuk para guru-guru berupa penyuluhan dan sosialisasi. Kegiatan ini dilakukan dengan metode ceramah dan dilanjutkan dengan diskusi. Materi penyuluhan terdiri dari pengertian pembelajaran daring, konsep pembelajaran daring, pengenalan hambatan-hambatan pembelajaran daring (Jamaluddin, 2020), cara pemberian pembelajaran daring yang interaktif dan mengenal aplikasi yang digunakan untuk menjadikan proses pembelajaran menjadi menjadi interaktif, langkah untuk membeuat dan merancang pembelajaran dengan menggunakan aplikasi pembelajaran daring yang interaktif.

\section{HASIL DAN PEMBAHASAN}

Penyuluhan dan sosialisasi pembelajaran daring dimaksudkan untuk memberikan gambaran tentang cara membuat pembelajaran daring di Perguruan Islam Miftahul Husna lebih menarik dan interaktif. Sebagaimana diketahui bahwa pembelajaran daring yang menarik dan interaktif bergantung pada kesiapan guru dalam menyajikan proses pembelajaran. Dengan memberikan sosialisasi kepada para peserta, diharapkan dapat memperoleh pengetahuan bagaimana menyajikan pembelajaran daring yang menarik serta menambah pengetahuan mereka akan opsi aplikasi apa saja yang bisa dipakai saat pembelajaran daring. Sosialisasi ini diikuti 25 orang yang merupakan seluruh guru perguruan 
Islam Miftahul Husna. Pada pelaksanan penyuluhan dan sosialisasi pelatihan tersebut juga dilakukan penyerahan modul pembelajaran penggunaan aplikasi yang diperlukan selama pelatihan.

Penyuluhan dan sosialisasi dilaksanakan di Perguruan Islam Miftahul Husna dimaksudkan untuk memudahkan peserta dalam melakukan pembelajaran daring yang menarik dikarenakan pembelajaran yang selama ini dilakukan diketahui sangat monoton dan memang sangat banyak ditemui diberbagai sekolah karena pembelajaran model ini dipandang sangat baru diakibatkan pandemi yang melanda. Penyuluhan ini juga diharapkan menjadi jawaban dan membantu peserta atas keluhan yang selama ini dialami. Banyak juga penelitian sebelumnya telah dilakukan untuk mengetahui kendala-kendala yang sering dijumpai para guru saat menyajikan proses pembelajaran daring. Diantaranya adalah menurut Rigianti (2020) banyak kendala yang dialami saat menyajikan pembelajaran daring dimulai aplikasi yang digunakan, pengelolaan pembelajaran, dan penilaian pembelajaran. Masing-masing dari kendala tersebut juga dirasakan oleh guru-guru perguruan Miftahul Husna.

Berangkat dari masalah tersebut maka tujuan dari penyuluhan dan sosialisi ini adalah membantu para guru menemukan media pembelajaran daring yang interaktif dan menyenangkan. Selain itu para siswa juga dapat belajar dengan interaktif dan menarik motivasi siswa sekalipun dengan pembelajaran daring. Saat kegiatan berlangsung guru-guru dipaparkan materi dan pengenalan akan pembelajaran daring serta media pembelajaran. Pembelajaran sistem daring disini dapat menggunakan gawai atau berbasis web yang tidak memiliki batasan akses. Menurut Michael (2013), Chandrawati (2010), Ardiansyah (2013), Setiawan (2020) Pembelajaran daring yang dapat pula disebut dengan e-learning merupakan proses pembelajaran jarak jauh dimana tidak perlu diadakannya tatap muka antara pengajar dan siswa namun dapat digantikan dengan menggunakan elektronik sehingga mampu mendukung suatu proses pembelajran dimana proses pembelajaran ini menggabungkan prinsip pembelajaran jarak jauh dan penggunaan teknologi. Pembelajaran daring termasuk model pembelajaran yang berpusat pada peserta didik dan pembelajaran daring ini menuntut keaktifan mereka dalam belajar. Jika peserta didik semakin aktif dalam daring maka akan semakin banyak pengetahuan dan kecakapan yang dapat mereka temui dalam proses pembelajaran.

Materi lain yang disampaikan saat dilakukannya sosialisasi ini adalah mengenai media pembelajaran. Media pembelajaran sangat dibutuhkan untuk membuat proses pembelajaran bisa menjadi interaktif dan menyenangkan. Media yang dipilih khususnya dalam pembelajaran daring ini haruslah media yang tetap membuat para siswa tertarik untuk belajar dan juga yang dapat dengan mudah dilakukan oleh para guru. Media pembelajaran merupakan media atau alat komponen sumber belajar baik hardware ataupun software yang digunakan untuk membantu komunikasi dan interaksi guru dan siswa dalam proses pembelajaran. Komponen ini dapat berupa pesan, orang, material, teknik dan lingkungan yang melibatkan pancaindra sehingga dapat dilihat, didengar, atau diraba (Jennah, 2009). Menurut Nurseto (2011) untuk mengembangkan media pembelajaran perlu diperhatikan prinsip VISUAL yang digambarkan dari singkatan kata-kata Visible (mudah dilihat), Interesting (Menarik), Simple (Sederhana), Useful (Isinya berguna/bermanfaat), Accurate (benar/dapat dipertanggungjawabkan), Legitimate (masuk akal), Strucured (terstruktur).

Setelah peserta diberi materi tentang pembelajaran daring dan media pembelajaran, peserta diarahkan lebih fokus untuk mengetahui beberapa aplikasi yang digunakan dalam pembelajaran daring yang menarik dan dapat meningkatkan motivasi siswa dalam belajar. Salah satu media yang dipilih dalam sosialisasi ini adalah adalah aplikasi Kahoot. Media Kahoot adalah media pembelajaran online berbasis pertanyaan tidak berbayar yang digunakan dalam proses pembelajaran dalam rangka mengevaluasi hasil proses belajar siswa.

Penggunaan media Kahoot memiliki beberapa keuntungan untuk guru dan siswa karena bisa digunakan dalam mata pelajaran apa pun dan memberikan manfaat kepada siswa 
dimana mereka dapat terbantu dalam mengingat kembali materi yang telah diberikan. Media pembelajaran ini juga dapat membuat mereka lebih bersemangat, merasa senang, tidak merasa bosan dan dapat berpartisipasi dengan aktif dalam mengerjakan latihan-latihan karena media ini menyajikan soal dalam bentuk quiz yang disajikan berwarna dan kompetitif. Media ini juga dapat membantu dan memudahkan para guru untuk mengevaluasi pekerjaan siswa.

Saat pelatihan dijelaskan juga bahwa saat menggunakan media pembelajaran Kahoot siswa dapat berdiskusi dan berkolaborasi dalam menjawab pertanyaan-pertanyaan yang ditayangkan di layar. Game Kahoot yang memunculkan kompetisi diantara para siswa sehingga mereka tertantang untuk menjadi yang terbaik di kelas. Penggunaan media Kahoot ini dapat menumbuhkan minat dan motivasi siswa dalam belajar. Dengan peningkatan minat dan motivasi ini, maka guru-gur dapat menjadikan Kahoot menjadi salah satu alternatif pembelajaran saat daring. Setelah mengetahui keuntungan dan kelebihan dari penggunaan media ini, para peserta diajak untuk membuat dan mengembangan media pembelajaran mereka masing-masing sesuai dengan mata pelajaran yang diajarkan dengan aplikasi kahoot ini.

Seluruh peserta pelatihan dan sosialisasi ini begitu bersemangat mengikuti setiap tahapan pengembangan media pembelajaran menggunakan kahoot dari mulai awal masuk mengakses atau mendownload aplikasi kahoot di gawai atau di leptop masing-masing, mendaftarkan dengan menggunakan email, membuat akun sampai merancang quiz tiap-tiap mata pelajaran dengan mengikuti arahan yang disampaikan oleh pemateri dan mengikuti modul yang telah disediakan, sampai akhir pengujian media masing-masing yang telah dibuat.

Pelatihan pembuatan media pembelajaran yang interaktif dan menarik dengan media kahoot ini memberi keuntungan bagi proses pembelajaran. Hal ini terlihat saat pengujian media yang telah dibuat oleh masing-masing guru. Peserta tampak meningkat motivasinya saat disajikan quiz dengan kahoot ini. Motivasi dapat mempengaruhi apa yang telah dipelajari, bagaimana mempelajari dan terlihat juga jika peserta termotivasi maka mereka akan menunjukkan sikap lebih cenderung melakukan kegiatan dengan terlibat aktif, menikmati proses kegiatandan menunjukkan peningkatan hasil belajar. selain itu dengan meningkatnya motivasi belajar hal ini akan merancang lingkungan belajar yg aktif dan menarik perhatian dari peserta didik (Fitriyani, 2020)

\section{SIMPULAN DAN SARAN}

Berdasarkan analisis hasil kegiatan dapat disimpulkan beberapa hal sebagai berikut: Setelah dilakukan pelatihan, guru-guru Perguruan Islam Miftahul Husna mengenal beberapa aplikasi-aplikasi dan cara menggunakannya untuk merancang dan mengembangkan pembelajaran daring yang menarik dan interaktif. Minat dan kesadaran para guru meningkat untuk membuat dan mengembangakan pembelajaran daring yang menarik dan interaktif. Para siswa juga meningkat motivasinya dalam belajar sekalipun masih belajar dari rumah dengan sistem daring.

\section{DAFTAR PUSTAKA}

Allen, Michael. (2013) Michael Allen's Guide to E-learning. Canada: John Willey \& Sons

Ardiansyah, I. (2013) Eksplorasi Pola Komunikasi dalam Diskusi Menggunakan Moddle pada Perkuliahan Simulasi Pembelajaran Kimia. Bandung: Universitas Pendidikan Indonesia

Chandrawati, S. R. (2010). Pemanfaatan Elearning dalam Pembelajaran. No 2 Vol. 8. http://jurnal.untan.ac.id/

Fitriyani, Y., Fauzi, I., Sari, M. Z. (2020) Motivasi Belajar Mahasiswa Pada Pembelajaran Daring Selama Pandemik Covid-19. Jurnal Kependidikan: Jurnal Hasil Penelitian dan Kajian Kepustakaan di Bidang Pendidikan, Pengajaran dan Pembelajaran. 6 (2) : 165-175. Doi: https://doi.org/10.33394/jk.v6i2.2654

Jamaluddin, D. Et al. (2020) Pembelajaran Daring Masa Pandemik Covid-19 Pada Calon Guru: Hambatan, Solusi dan Proyeksi. Karya Tulis Ilmiah, Lembaga Penelitian dan Pengabdian Kepada Masyarakat UIN Sunan Gunung Djati Bandung 
Jennah, R. (2009). Media Pembelajaran: Antasari Press. Ash-Shaff

Marbun, P (2020). Disain Pembelajaran Online Pada Era dan Pasca Covid-19. CSRID Journal $12 \quad$ (2) : 129-142. Doi: 10.22303/csrid.12.2.2020.129-142

Nurseto, T. (2011). Membuat Media Pembelajaran yang Menarik. Jurnal Ekonomi dan Pendidikan. 8 (2) : 19-35. Doi: https://doi.org/10.21831/jep.v8i1.706

Putranti, N. (2013). Cara Membuat Media Pembelajaran Online Menggunakan EDMODO. Jurnal Pendidikan Informatika dan Sains 2 (2) : 139-147

Rigianti，H. A. (2020) Kendala Pembelajaran Daring Guru Sekolah Dasar Di Kabupaten Banjarnegara. Elementary School 7 (2): 297302

Setiawan, P. (2020) Pengertian E-learning Menurut Para Ahli Karakteristik E-Learning Manfaat E-Learning

Simbolon, G., Elnovreny, J. (2020). Improving Citizen's Life Skill Learning by Tenun Training. KOLOKIUM Jurnal Pendidikan Luar Sekolah 8 (2) : 171-175. Doi: 10.24036/kolokium-pls.v8i2.402 